\title{
sn-1,2-Diacylglycerols and Phorbol Diesters Stimulate Thromboxane Synthesis by De Novo Synthesis of Prostaglandin H Synthase in Human Promyelocytic Leukemia Cells
}

\author{
Matthias Goerig, Andreas J. R. Habenicht, Roselinde Heitz, Wolfgang Zeh, Hugo Katus, \\ Burkhard Kommerell, Reinhard Ziegler, and John A. Glomset* \\ Medical Clinic, University of Heidelberg, D-6900 Heidelberg, Federal Republic of Germany; and *Howard Hughes Medical Institute \\ Laboratory SL-15, Regional Primate Research Center, University of Washington, Seattle, Washington 98195
}

\begin{abstract}
We studied the regulation of thromboxane (TX) synthesis in promyelocytic leukemia cells during macrophage differentiation. Cells treated with 12-O-tetradecanoylphorbol-13-acetate (TPA) showed rates of $\mathbf{T X B}_{2}$ synthesis from exogenous arachidonic acid that exceeded that of control cells by a factor of up to 81 . Cells treated with sn-1,2-dioctanoylglycerol (diC8) showed similarly high $\mathrm{TXB}_{2}$ synthesis rates when diC8 was added concomitantly with a subthreshold concentration of TPA or when given in multiple doses. These activities depended on de novo synthesis of prostaglandin $\mathrm{H}$ (PGH) synthase because: (a) microsomal PGH synthase activity showed large increases in $\boldsymbol{V}_{\max }$ values, and (b) mass measurements of PGH synthase revealed the presence of PGH synthase in differentiating cells whereas the enzyme was undetectable in control cells. These results indicate that macrophage differentiation is associated with stimulation of $\mathbf{T X B}_{2}$ synthesis that requires both activation of protein kinase $C$ and de novo synthesis of PGH synthase.
\end{abstract}

\section{Introduction}

Infiltration of monocytes into affected tissues occurs in diseases as varied as rheumatoid arthritis (1), chronic inflammatory bowel disease (2), hydronephrosis (3-5), and atherosclerosis (6), whereupon the monocytes undergo extensive morphologic and functional alterations that resemble those observed after induction of macrophage differentiation in vitro (7-9). Thus monocyte infiltration and differentiation are clearly key events in the inflammatory process.

To understand these events better, it will be necessary to establish the sequence of reactions that underlies monocyte/ macrophage differentiation and to identify the control mechanisms that are involved. One such mechanism may depend on

Preliminary results of this study were presented at the Sixth International Conference on Prostaglandins and Related Compounds, Florence, Italy, 3-6 June 1986.

Address reprint requests to Dr. Goerig, Medical Clinic, University of Heidelberg, Bergheimerstrasse 58, D-6900 Heidelberg, Federal Republic of Germany.

Received for publication 3 September 1986.

\section{J. Clin. Invest.}

(C) The American Society for Clinical Investigation, Inc.

0021-9738/87/03/0903/09 \$1.00

Volume 79, March 1987, 903-911 the synthesis of thromboxane (TX). ${ }^{1}$ Monocytes/macrophages, maintained in vitro, release TX along with other biologically active molecules $(3-5,10)$. Moreover, in vivo models of inflammation, such as the hydronephrotic kidney (5) and myocardial infarction $(11,12)$, have provided evidence that TX synthesized by monocytes/macrophages is important in modulating the inflammatory reaction at sites of tissue injury.

The objective of the present investigation was to obtain information about the regulation of TX synthesis in differentiating monocytes. We used differentiating HL-60 cells as a model system. Several studies $(7,8,13-15)$ have shown that these cells differentiate into macrophage-like cells in response to phorbol diesters, and evidence has indicated a close relation between the action of these esters and the activity of protein kinase C (PKC) (16-18). Furthermore, Ebeling et al. (13) added the cell-permeable diacylglycerol, dioctanoylglycerol (diC8), to HL-60 cells and showed that it was able to stimulate both PKC and cell adhesion. The same investigators showed that HL-60 macrophage differentiation only occurred after repeated addition of diC8 and that repeated addition of diC8 induced persistent occupancy of the phorbol diester binding site. In contrast, a single addition of diC8 led to transient occupancy of the phorbol diester binding site and did not induce macrophage differentiation, and a recent report by May et al. (15) showed that diC8 was rapidly phosphorylated to form phosphatidic acid in HL-60 cells. These results, in particular, strongly suggested that PKC activationif maintained for several hours-is a key event in macrophage differentiation.

We therefore used either 12-O-tetradecanoylphorbol-13-acetate (TPA) or diC8 to initiate macrophage differentiation, and asked the following questions: $(a)$ When during the course of monocyte/macrophage differentiation is the prostaglandin $\mathbf{H}$ (PGH) synthase pathway activated? $(b)$ Does the regulation of this pathway involve PKC? and (c) does it involve formation of PGH synthase? Our results provide new information regarding the control of $\mathrm{TXB}_{2}$ synthesis during the early stages of macrophage differentiation in vitro.

\section{Methods}

Materials. Cell culture media were obtained from Gibco, Grand Island, NY; standard PGs were obtained from Seragen, Boston, MA; $\left[{ }^{3} \mathrm{H}\right] \mathrm{TXB}_{2}$ (sp act $139 \mathrm{Ci} / \mathrm{mmol}$ ), $\left[{ }^{3} \mathrm{H}\right] \mathrm{PGE}_{2}$ (sp act $120 \mathrm{Ci} / \mathrm{mmol}$ ), [ $\left.{ }^{3} \mathrm{H}\right] 6-k e t o-P F_{1 \alpha}$

1. Abbreviations used in this paper: AA, arachidonic acid; ALP, alkyl-lysophospholipid; diC8, sn-1,2-dioctanoylglycerol; LDH, lactate dehydrogenase; PDS, plasma-derived serum; PKC, protein kinase C; TFP, trifluoperazine; TPA, 12-O-tetradecanoylphorbol-13-acetate; TX, thromboxane. 
(sp act $120 \mathrm{Ci} / \mathrm{mmol}$ ) were obtained from New England Nuclear, Boston, MA; TPA, arachidonic acid (AA), and Protein A-Sepharose CL-4B were obtained from Pharmacia, Freiburg, Federal Republic of Germany; antibodies against icosanoids were obtained from the Institut Pasteur, Paris, France; monoclonal antibodies against sheep seminal vesicle PGH synthase (cyo-1, cyo-5) and partially purified sheep seminal vesicle PGH synthase were from Oxford Biomedical Research, Inc., Oxford, MI; H7 from Seikagaku America Inc., St. Petersburg, FL; $\mathrm{Ca}^{2+}$ ionophore A23187, cycloheximide, and all other reagents were from Sigma Chemical Co., Munich, Federal Republic of Germany; diC8 at $3 \mathrm{M}$ and TPA at $10 \mathrm{mM}$ in acetone was stored under argon at $-80^{\circ} \mathrm{C}$. Double-distilled $\mathrm{H}_{2} \mathrm{O}$ was used throughout.

Cell culture. The human promyelocytic leukemia cell line HL-60 was obtained from the American Type Culture Collection, Rockville, MD, and maintained in RPMI 1640 medium containing $10 \%$ fetal calf serum, $100 \mathrm{U} /$ liter penicillin, and $100 \mu \mathrm{g} / \mathrm{ml}$ streptomycin. Experiments designed to determine levels of $\mathrm{TXB}_{2}$ were performed in $5 \%$ calf plasmaderived serum (PDS) $(19,20)$ because $\mathrm{TXB}_{2}$ in PDS was not detectable whereas that in $5 \%$ fetal calf serum ranged between 300 and $800 \mathrm{pg} / \mathrm{ml}$. The diC8 and $\mathrm{Ca}^{2+}$ ionophore $\mathrm{A} 23187$ were added to cells in concentrated solutions of 2-5 $\mu \mathrm{l}$ acetone or $6 \mu \mathrm{l}$ ethanol, respectively, to give the concentrations indicated in the figure legends. Control cells received acetone or ethanol instead. Cell viability tests were performed under all experimental conditions by both trypan blue exclusion and release of lactate dehydrogenase (LDH): $>95 \%$ of the cells excluded trypan blue and significant release of $\mathrm{LDH}$ was obtained only at concentrations of TPA beyond $200 \mathrm{nM}$ or concentrations of diC8 beyond $150 \mu \mathrm{M}$.

Radioimmunoassay $(R I A)$. The concentration of icosanoids was determined by RIA according to Granstroem and Kindahl (21) after reversed-phase extraction and thin-layer chromatography as described previously for $\mathrm{PGE}_{2}$ and 6-keto-PGF $\mathrm{P}_{1 \alpha}(19,20)$. Total recovery for $\mathrm{TXB}_{2}$ ranged between $44 \%$ and $67 \%$, cross-reactivity at $50 \%$ binding was $<0.2 \%$ for $\mathrm{PGA}_{2}, \mathrm{PGB}_{2}, \mathrm{PGE}_{2}, \mathrm{PGD}_{2}, \mathrm{PGF}_{2 \alpha}, 6$-keto-PGF $1 \alpha, \mathrm{AA}$, and $\mathrm{PGH}_{2}$. Water samples subjected to exactly the same analytical procedure as biological samples ranged between 1 and $4 \mathrm{pg} / \mathrm{ml}$, intraassay variation was $6 \%-11 \%$, and interassay variation was $9 \%-14 \%$.

Estimation of HL-60 PGH synthase mass. The amount of PGH synthase protein in HL-60 cells was estimated by using two monoclonal antibodies directed against different antigenic sites on sheep seminal vesicle PGH synthase (cyo-1, cyo-5) $(22,23)$. Solubilized microsomes were prepared as described under the subsection "Assay of microsomal PGH synthase activity" except that the microsomes were taken up in assay buffer ( $50 \mathrm{mM}$ Tris, pH 7.8, $2 \mathrm{mM}$ EDTA, $0.25 \mathrm{M}$ sucrose, $0.15 \%$ Tween 20). Purification of cyo- 1 and cyo- 5 antibodies: $15 \mathrm{ml}$ of culture medium containing the cyo-1 and cyo-5 antibodies, respectively, was purified by Protein A-Sepharose column chromatography as described by Smith and Rollins (22). Purified cyo-1 antibody was iodinated with ${ }^{125} \mathrm{I}$ using chloramine T (24) (sp act $20,350 \mathrm{dpm} / \mathrm{ng}$ of protein). $50 \mu \mathrm{l}$ of $125 \mathrm{mM}$ borate buffer, $\mathrm{pH} 8.4$, containing $2 \mu \mathrm{g}$ of purified unlabeled cyo- 5 antibody was incubated in microtiter plates (Flow General Inc., McLean, VA) for $18 \mathrm{~h}$ at $4^{\circ} \mathrm{C}$. Solubilized HL-60 microsomes or partially purified sheep seminal vesicle PGH synthase dissolved in $50 \mu \mathrm{l}$ of assay buffer was added and incubated for $75 \mathrm{~min}$ at room temperature; the plates were incubated with buffer ( $1 \%$ Tween $20,5 \%$ bovine serum albumin dissolved in phosphate-buffered saline, $\mathrm{pH} \mathrm{7.4)} \mathrm{for} 10 \mathrm{~min}$ at room temperature. $50 \mu \mathrm{l}$ of buffer containing purified ${ }^{125} \mathrm{I}$-iodinated cyo-1 antibody $(53,000$ $\mathrm{dpm}$ ) was added and incubated for $50 \mathrm{~min}$ at room temperature. Bound radioactivity was counted in a LKB Wallac 1280 Ultragamma scintillation spectrometer (LKB Produkter, Bromma, Sweden). Background samples that did not contain unlabeled antibody (cyo-5), solubilized HL-60 microsomes, or standard PGH synthase ranged between 15\%-20\% of the biological samples. Standard curves were generated using PGH synthase partially purified from sheep seminal vesicle microsomes. The results obtained with HL-60 cells are reported in picograms of partially purified sheep seminal vesicle PGH synthase per microgram of HL-60 microsomal protein.

Assay of microsomal PGH synthase activity. PGH synthase activity was determined according to Sheng et al. (4) and Whiteley and Nee- dleman (26) with minor modifications. Briefly, HL-60 cells were cultured as described under cell culture. HL-60 cells at a density of $1.0 \times 10^{6} / \mathrm{ml}$ were suspended in culture medium supplemented with 5\% PDS. Experimental solutions were added as described under cell culture and the cells were incubated for $12 \mathrm{~h}$. Then cells were washed twice with homogenization buffer ( $50 \mathrm{mM}$ Tris- $\mathrm{HCl}, 2 \mathrm{mM}$ EGTA, $0.3 \mathrm{mM} \mathrm{MgCl}$, $1 \%$ free fatty acid-free albumin, $25 \%$ sucrose, $\mathrm{pH} 7.8$ ), and cells at a density of $10^{7} / \mathrm{ml}$ were homogenized using a Tekmar homogenizer equipped with an 18-cm shaft (Janke und Kunkel, Staufen, Federal Republic of Germany) for $12 \times 10 \mathrm{~s}$ on ice in siliconized glass tubes under argon. The homogenate was centrifuged at $1,000 \mathrm{~g}$ for $5 \mathrm{~min}$ at $4^{\circ} \mathrm{C}$ to remove cell debris, nuclei, and mitochondria. The supernatant was transferred under argon to a polycarbonate tube and centrifuged at 55,000 $g$ for $15 \mathrm{~min}$. The resulting pellet was washed three times under argon on ice using $2 \mathrm{ml}$ of $50 \mathrm{mM}$ Tris buffer, pH 7.8, $2 \mathrm{mM}$ EGTA, 25\% sucrose. Protein was determined by the method of Lowry et al. (27). The reaction was started by addition of $20 \mu \mathrm{g}$ of microsomal protein that was suspended in $20 \mu \mathrm{l}$ of homogenization buffer to $480 \mu$ l of assay buffer ( $50 \mathrm{mM}$ Tris $\mathrm{HCl}, 2 \mathrm{mM}$ EGTA, $1 \mathrm{mM}$ reduced glutathione, 1.2 $\mathrm{mM}$ epinephrine) at $37^{\circ} \mathrm{C}$ for $7.5 \mathrm{~min}$. Before addition of microsomes, AA was added in a concentrated solution of $5 \mu \mathrm{l}$ of ethanol. The reaction was stopped by addition of $2.5 \mathrm{ml}$ of ice-cold PBS acidified to pH 3.4 and immediately extracted using Octadecyl silica gel columns as described (19). At concentrations of AA between 4 and $128 \mu \mathrm{M}$, the formation of $\mathrm{TXB}_{2}, \mathrm{PGE}_{2}$, and 6-keto-PGF ${ }_{1 \alpha}$ was linear for $12 \mathrm{~min}$. Formation of icosanoids was also linear with respect to microsomal protein (determined between 5 and $50 \mu \mathrm{g}$ ). Control microsomes boiled for $10 \mathrm{~min}$ or preincubated with $100 \mu \mathrm{M}$ aspirin for $25 \mathrm{~min}$ on ice did not contain measurable PGH synthase activity. Concentrations of icosanoids were determined by RIA as described above.

\section{Results}

TPA-dependent stimulation of $T X B_{2}$ synthesis from exogenous $\dot{A} A$. Preliminary experiments, performed with HL-60 cells that were incubated in the absence of unesterified AA, revealed that the TPA-induced differentiation of these cells into macrophages is accompanied by increased $\mathrm{TXB}_{2}$ synthesis. Unstimulated cells synthesized $20-105 \mathrm{pg}$ of $\mathrm{TXB}_{2} / 10^{6}$ cells per $12 \mathrm{~h}$, whereas cells that were stimulated with $10 \mathrm{nM}$ TPA synthesized from 3.7 to 9.8 times this amount (results not shown). These results extended to HL-60 cells the report of Ohuchi et al. (28) and others that phorbol diesters stimulate the synthesis of PGs in cells in culture.

To determine whether the action of TPA on HL-60 cells was associated with increased activity of enzymes in the PG synthesis pathway, we tested the effect of added unesterified AA on the synthesis of $\mathrm{TXB}_{2}$ in control and TPA-treated cells (Fig. 1). We found that $A A$ had little effect on $T X B_{2}$ synthesis in undifferentiated control cells, but increased $\mathrm{TXB}_{2}$ synthesis by as much as 81-fold in TPA-treated cells at a concentration of $10 \mu \mathrm{M}$.

Interestingly, the effect of the $\mathrm{Ca}^{2+}$ ionophore $\mathrm{A} 23187$ (29) on HL-60 cells resembled that of added AA. Undifferentiated cells that were treated with the ionophore produced little $\mathrm{TXB}_{2}$ in the presence or absence of AA. In contrast, TPA-treated cells that were incubated in the presence of 1-3 $\mu \mathrm{M}$ ionophore produced maximal amounts of $\mathrm{TXB}_{2}$ even in the absence of added AA (Fig. 2). Thus the ionophore seemed unable by itself to increase the activity of enzymes in the PG synthesis pathway. It was, however, able to stimulate $\mathrm{TXB}_{2}$ synthesis, presumably by promoting the release of AA from endogenous phospholipid stores.

To determine whether the effect of TPA on TXB 2 synthesis occurred early during the course of macrophage differentiation, 


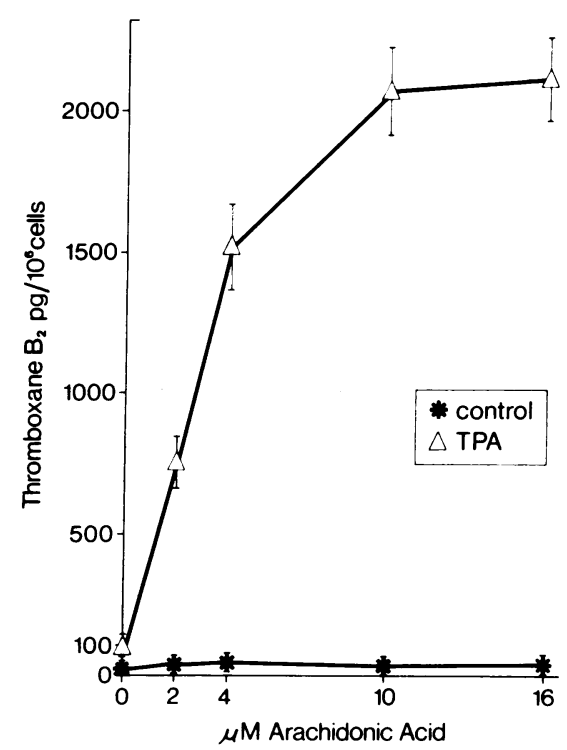

Figure 1. Concentration dependence of $\mathrm{TXB}_{2}$ synthesis from exogenous AA in undifferentiated and TPA-treated HL-60 cells. Cells at a density of $1 \times 10^{6} / \mathrm{ml}$ were cultured in $60-\mathrm{mm}$ Falcon plastic dishes in $5 \mathrm{ml}$ of RPMI 1640 medium supplemented with 5\% PDS. TPA dissolved in acetone was added to medium to give a final concentration of TPA of $10 \mathrm{nM}$ and $0.01 \%$ acetone or acetone as control. $11 \mathrm{~h}$ later parallel cultures were incubated with increasing concentrations of AA dissolved in a concentrated solution of $10 \mu$ l ethanol to give a final concentration of ethanol of $0.3 \%$ or ethanol as control. After $60 \mathrm{~min}$ the concentration of $\mathrm{TXB}_{2}$ was determined by RIA as described in Methods. The data points represent the means of three parallel dishes \pm standard deviation.

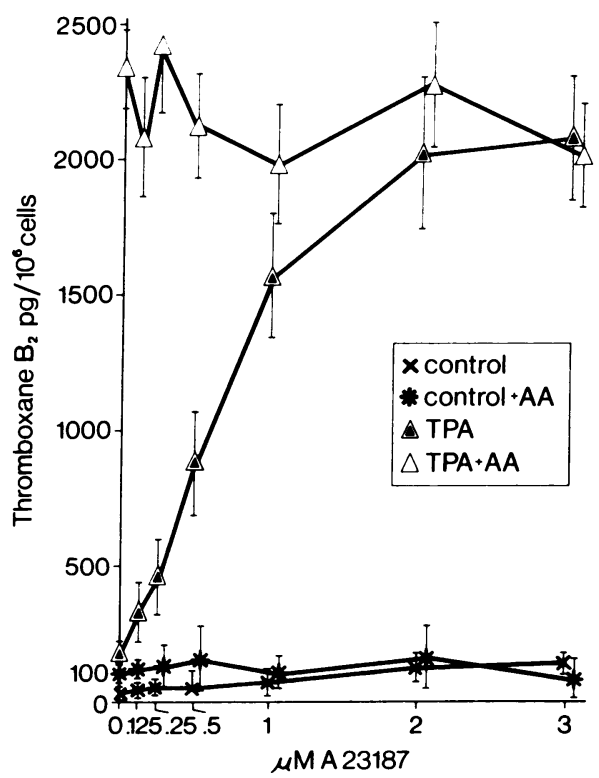

Figure 2. Effects of $\mathrm{Ca}^{2+}$ ionophore $\mathrm{A} 23187$ on $\mathrm{TXB}_{2}$ synthesis in control and TPA-treated HL-60 cells. Cells were cultured and TPA added as described in Fig. 1. $11 \mathrm{~h}$ later parallel cultures were incubated with increasing concentrations of $\mathrm{Ca}^{2+}$ ionophore A23187 dissolved in a concentrated solution of $10 \mu$ l of ethanol or ethanol in the presence of $10 \mu \mathrm{M} \mathrm{AA}$ as described in Fig. 1 and in Methods. $60 \mathrm{~min}$ later the concentration of $\mathrm{TXB}_{2}$ was determined as described in Methods. The data points represent means of duplicate determinations \pm standard deviation. we incubated HL-60 cells with TPA and measured the rate of $\mathrm{TXB}_{2}$ synthesis in the presence of added $\mathrm{AA}$ as a function of time (Fig. 3). We observed stimulatory effects of TPA within 1 $\mathrm{h}$, which increased sharply after $3 \mathrm{~h}$ and plateaued after 4-6 h. By comparison, TPA-induced adherence of the cells to the culture dish began after $12 \mathrm{~h}$, and $\sim 95 \%$ of the cells adhered to the dish and showed macrophage morphology (7) within $24 \mathrm{~h}$.

We next determined whether TPA stimulated the formation of other products of the PGH synthase pathway and found (Table I) that all major products of this pathway, $\mathrm{TXB}_{2}, \mathrm{PGE}_{2}$, and 6keto-PGF $F_{1 \alpha}$, increased in response to the phorbol diester. This raised the possibility that TPA may have promoted the activation of at least one enzyme involved in PG synthesis.

To determine whether the effect was specific for phorbol diesters that activate PKC, we used the phorbol diester, 4- $\alpha$ phorbol 12,13-didecanoate. This phorbol diester is unable to activate PKC in several biological systems (30). We found that it was also unable to stimulate $\mathbf{T X B}_{2}$ synthesis and induce cell adherence in HL- 60 cells, even when its concentration exceeded the maximal concentration of TPA by two orders of magnitude (not shown).

Diacylglycerol-dependent synthesis of $T X B_{2}$. Experiments with the cell-permeable diacylglycerol, $\operatorname{diC} 8(15,16)$, provided further evidence for a relation between PKC activation, TXB $_{2}$ synthesis, and macrophage differentiation. We added diC8 to undifferentiated cells and determined the ability of the cells to produce $\mathrm{TXB}_{2}$ in the presence of added AA. $90 \mu \mathrm{M}$ diC8 significantly stimulated $\mathrm{TXB}_{2}$ synthesis (Fig. $4 \mathrm{~A}$ ), reaching $27 \%$ of the maximal TPA effect (Fig. $4 \mathrm{~B}$ ). Moreover, when a subthreshold concentration of TPA $(0.1 \mathrm{nM})$ was included in the culture medium, concentrations of diC8 between 10 and $30 \mu \mathrm{M}$ induced maximal synthesis of $\mathrm{TXB}_{2}$ (Fig. $4 \mathrm{~A}$ ). Other species of diacylglycerol, such as didecanoate and 1-oleoyl-2-acetyl diacylglycerol, also showed synergistic effects in the presence of subthreshold concentrations of TPA although they were not as active as $\mathrm{diC} 8$ (results not shown).

We next determined the kinetics of diC8-dependent $\mathrm{TXB}_{2}$ synthesis in the presence of $0.1 \mathrm{nM}$ TPA (Fig. 5). We found that diC8 significantly stimulated the synthesis of $\mathrm{TXB}_{2}$ (Fig. 5), $\mathrm{PGE}_{2}$, and 6-keto-PGF ${ }_{1 \alpha}$ (results not shown) within $1 \mathrm{~h}$ and its effect was maximal within 4-6 h. Because Ebeling et al. (13) had previously shown that diC 8 is relatively inactive when added at

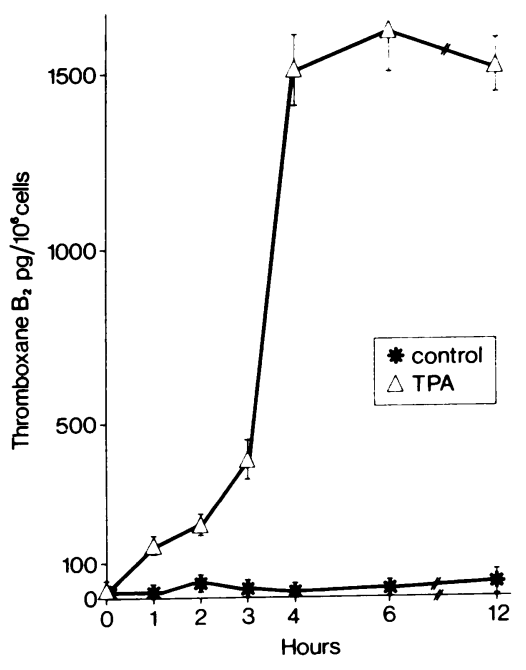

Figure 3. Kinetics of TPA-dependent $\mathrm{TXB}_{2}$ synthesis from exogenous AA. Cells were cultured and TPA added as described in Fig. 1.60 min before the time points indicated in the Figure, AA at $10 \mu \mathrm{M}$ was added to the cultures and the concentration of $\mathrm{TXB}_{2}$ was determined as described in Methods. The data points represent means of duplicate dishes \pm standard deviation. 
Table I. TPA-induced Macrophage Differentiation Is Associated with Enhanced Synthesis of the Major Products of the PGH Synthase Pathway from Exogenous $A A$

\begin{tabular}{lcr}
\hline Icosanoid & Control & \multicolumn{1}{c}{ TPA } \\
\hline & $p g / 10^{6}$ cells & $p g / 10^{6}$ cells \\
$\mathrm{TXB}_{2}$ & $38 \pm 19$ & $1,432 \pm 68$ \\
PGE $_{2}$ & $105 \pm 14$ & $987 \pm 59$ \\
6-keto-PGF & $52 \pm 26$ & $252 \pm 35$ \\
\hline
\end{tabular}

Cells were cultured and TPA was added as described in Fig. $1.11 \mathrm{~h}$ later, control and TPA-stimulated cells were incubated for an additional $60 \mathrm{~min}$ in the presence of $10 \mu \mathrm{M}$ AA and the concentration of icosanoids was determined as described in Methods. Numbers represent means of triplicate cultures \pm standard deviation.

a single dose, but induces macrophage differentiation when added repeatedly at hourly intervals, we used a similar approach to determine whether maximal effects of $\mathrm{diC} 8$ on $\mathrm{TXB}_{2}$ synthesis could be achieved in the absence of TPA. We added diC 8 at an initial loading dose of $30 \mu \mathrm{M}$ and in hourly maintenance doses of $10 \mu \mathrm{M}$, then measured the synthesis of $\mathrm{TXB}_{2}$ from exogenous $\mathrm{AA}$ at a fixed time interval, 11-12 $\mathrm{h}$ after addition of the initial dose of diC8. As shown in Fig. 6 diC8 maximally stimulated $\mathrm{TXB}_{2}$ synthesis when this dosage regimen was maintained for at least $5 \mathrm{~h}$. Furthermore, diC8-dependent synthesis correlated closely with diC8-dependent cell adhesion. When a single low dose $(30 \mu \mathrm{M})$ or high doses $(90-140 \mu \mathrm{M})$ of diC8 was added to the cells, no more than $2 \%-5 \%$ of the cells attached to the dish within $48 \mathrm{~h}$. In contrast, when the cells were given a loading

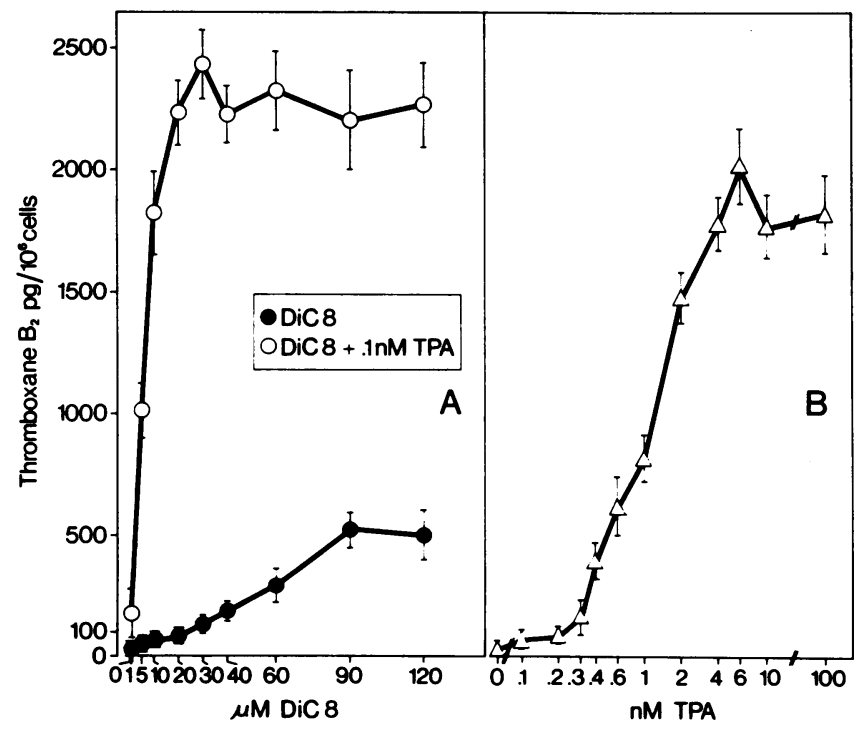

Figure 4. The diC8 and TPA synergistically stimulate $\mathrm{TXB}_{2}$ synthesis. Cells were cultured as described in Fig. 1. $(A)$ TPA and diC8 were added in concentrated solutions of acetone to give a concentration of $0.07 \%$ of acetone or acetone. $(B)$ TPA was added in a concentrated solution to give a final concentration of acetone of $0.01 \%$ or acetone. After $11 \mathrm{~h}$ parallel cultures were incubated with $10 \mu \mathrm{M}$ AA for $60 \mathrm{~min}$ and the concentration of $\mathrm{TXB}_{2}$ was determined as described in Methods. The data points represent means of duplicate dishes \pm standard deviation.

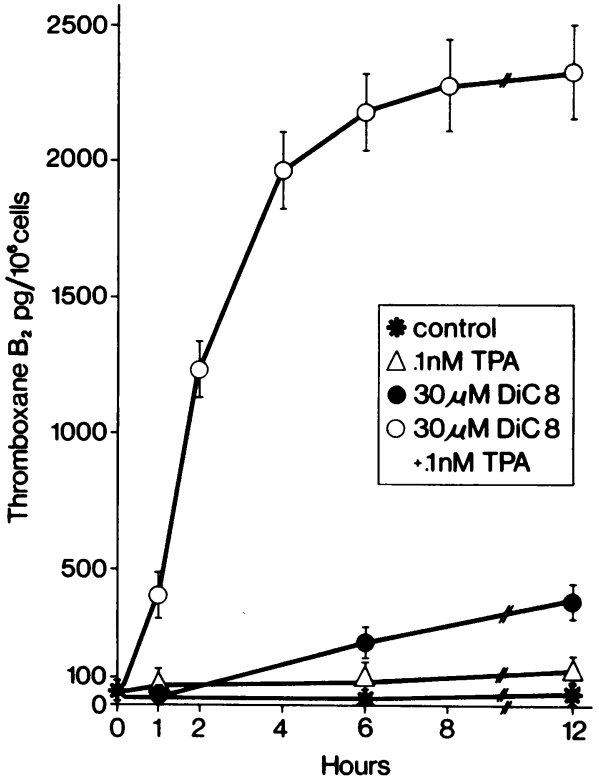

Figure 5. Kinetics of diC8-dependent $\mathrm{TXB}_{2}$ synthesis in the presence of $0.1 \mathrm{nM}$ TPA. Cells were cultured and $30 \mu \mathrm{M}$ diC8 and $0.1 \mathrm{nM}$

TPA added as described in Fig. $4.60 \mathrm{~min}$ before the time points indicated in the figure, parallel cultures were incubated with $10 \mu \mathrm{M}$ AA and the concentration of $\mathrm{TXB}_{2}$ was determined as described in Methods. The data points represent means of duplicate dishes \pm standard deviation.

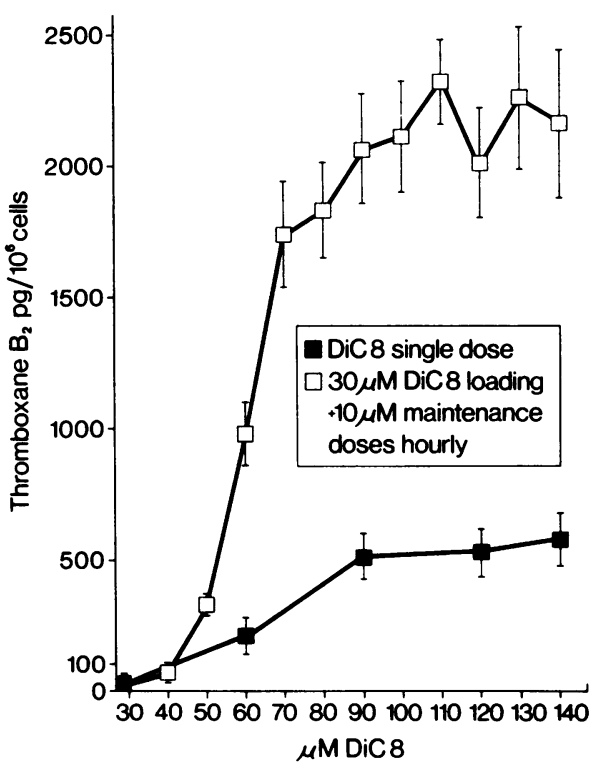

Figure 6. When given at multiple doses diC8 induces maximal $\mathrm{TXB}_{2}$ synthesis. Cells were cultured as described in Fig. 1 and a loading dose of $30 \mu \mathrm{M} \mathrm{diC} 8$ dissolved in a concentrated solution of $3 \mu \mathrm{l}$ of acetone or acetone as control was added. Parallel cultures received additional maintenance doses at $10 \mu \mathrm{M}$ diC 8 dissolved in a concentrated solution of $3 \mu \mathrm{l}$ acetone or acetone as control at hourly intervals for increasing time periods. The cultures were incubated with $10 \mu \mathrm{M}$ AA at $11 \mathrm{~h}$ for $60 \mathrm{~min}$ and the concentration of $\mathrm{TXB}_{2}$ was determined as described in Methods. $10 \mathrm{nM}$ TPA induced synthesis of 2,160 $\pm 193 \mathrm{pg}$ $\mathrm{TXB}_{2} / 10^{6}$ cells, and $140 \mu \mathrm{M}$ diC8 added at a single dose induced $634 \pm 68 \mathrm{pg} \mathrm{TXB}_{2} / 10^{6}$ cells in this experiment. Repeated addition of diC8 or acetone did not compromise viability as determined by trypan blue exclusion. The data points represent means of duplicate dishes \pm standard deviation. 
dose of $30 \mu \mathrm{M}$ diC8 followed by four hourly maintenance doses of $10 \mu \mathrm{M}$ diC8, $>95 \%$ of the cells attached within $24 \mathrm{~h}$.

Trifluoperazine (TFP) has previously been shown to inhibit the activity of PKC in HL-60 cells and the activity of PKC purified from bovine heart (31-33). We therefore determined whether TFP was able to inhibit the effect of TPA on $\mathrm{TXB}_{2}$ synthesis. We found that TFP did indeed inhibit this effect (Table II), and that the concentrations of TFP required were similar to those reported to inhibit PKC-dependent protein phosphorylation in HL-60 cells (32). Furthermore, there was a close correlation between the concentrations of TFP required to inhibit $\mathrm{TXB}_{2}$ synthesis and those required to inhibit HL-60 macrophage differentiation (results not shown). The alkyllysophospholipid, ET-18- $\mathrm{OCH}_{3}$ (ALP), and the lipoidal amine, CP-46,665-1 (CP), have been shown to inhibit PKC in HL-60 cells $(34,35)$ by competing with the phospholipid activator of PKC phosphatid-

Table II. Inhibitors of PKC Prevent Both TPA-induced Macrophage Differentiation and Synthesis of $T X B_{2}$

\begin{tabular}{lc}
\hline Additions & \multicolumn{1}{c}{$\mathrm{TXB}_{2}$} \\
\hline & $p g / 10^{6}$ cells \\
Experiment I & \\
Control & $24 \pm 6$ \\
$10 \mathrm{nM}$ TPA & $1,964 \pm 206$ \\
$10 \mathrm{nM}$ TPA $+1 \mu \mathrm{M}$ TFP & $1,320 \pm 134$ \\
$10 \mathrm{nM}$ TPA $+5 \mu \mathrm{M}$ TFP & $840 \pm 128$ \\
$10 \mathrm{nM}$ TPA $+50 \mu \mathrm{M}$ TFP & $547 \pm 105$ \\
& \\
Experiment II & $84 \pm 21$ \\
Control & $2,214 \pm 320$ \\
$10 \mathrm{nM}$ TPA & $1,610 \pm 135$ \\
$10 \mathrm{nM}$ TPA $+1 \mu \mathrm{M}$ ALP & $716 \pm 205$ \\
$10 \mathrm{nM}$ TPA $+5 \mu \mathrm{M}$ ALP & $1,688 \pm 267$ \\
$10 \mathrm{nM}$ TPA $+500 \mathrm{nM} \mathrm{CP}$ & $1,240 \pm 184$ \\
$10 \mathrm{nM}$ TPA $+1 \mu \mathrm{M}$ CP & $589 \pm 183$ \\
$10 \mathrm{nM}$ TPA $+5 \mu \mathrm{M}$ CP & \\
Experiment III & $35 \pm 14$ \\
Control & \\
$10 \mathrm{nM}$ TPA & \\
$10 \mathrm{nM}$ TPA $+10 \mu \mathrm{M}$ H-7 & $2,250 \pm 165$ \\
$10 \mathrm{nM}$ TPA $+50 \mu \mathrm{M}$ H-7 & $1,860 \pm 167$ \\
$10 \mathrm{nM}$ TPA $+100 \mu \mathrm{M}$ H-7 & $1,580 \pm 208$ \\
\end{tabular}

Cells were cultured and TPA added as described in Fig. $1.60 \mathrm{~min}$ before addition of TPA, TFP, ALP, CP, or H-7 at the indicated concentrations dissolved in 50 or $30 \mu$ PBS were added to parallel cultures. $11 \mathrm{~h}$ later the cultures were incubated with $10 \mu \mathrm{M}$ AA and $60 \mathrm{~min}$ later the concentration of $\mathrm{TXB}_{2}$ was determined as described in Methods. It is noteworthy that TFP at $50 \mu \mathrm{M}$ almost completely prevented HL-60 cell adhesion, ALP at $1 \mu \mathrm{M}$ only moderately prevented HL-60 cell adhesion assayed after $24 \mathrm{~h}$ whereas $5 \mu \mathrm{M}$ almost completely prevented HL-60 cell adhesion. CP at $1 \mu \mathrm{M}$ reduced TPA-induced HL-60 cell adhesion by $50 \%$ whereas it completely prevented HL- 60 cell adhesion at $5 \mu \mathrm{M}$. Likewise, $\mathrm{H}-7$ at $10 \mu \mathrm{M}$ had a small effect although it strongly inhibited HL-60 cell adhesion at $100 \mu \mathrm{M}$. TFP up to 50 $\mu \mathrm{M}, \mathrm{ALP}$ and and CP up to $5 \mu \mathrm{M}$, and $\mathrm{H}-7$ up to $100 \mu \mathrm{M}$ did not compromise viability as determined by exclusion of trypan blue $24 \mathrm{~h}$ after addition of TPA. TFP, ALP, CP, and $\mathrm{H}-7$ did not interfere with radioimmunologic determination of $\mathrm{TXB}_{2}$. The numbers represent means of duplicate dishes \pm standard deviation. ylserine. We therefore tested whether ALP and CP were able to inhibit TPA-induced $\mathrm{TXB}_{2}$ synthesis as well as macrophage differentiation. Both compounds largely prevented TPA-induced macrophage differentiation and $\mathrm{TXB}_{2}$ synthesis in a concentration dependent manner (Table II). The isoquinolinesulfonamide, H-7, has been shown to reversibly inhibit both cyclic AMPdependent protein kinase and PKC by competing with substrate ATP (36). H-7 also inhibited both TPA-induced macrophage differentiation and $\mathrm{TXB}_{2}$ synthesis (Table II).

The stimulation of $T X B_{2}$ synthesis by TPA and diC8 is associated with induction of PGH synthase. The synthesis of $\mathrm{TXB}_{2}$ that occurred early during macrophage differentiation of $\mathrm{HL}$ 60 cells required translational activity because $10 \mu \mathrm{g} / \mathrm{ml}$ cycloheximide completely prevented the diC8- and TPA-dependent synthesis of $\mathrm{TXB}_{2}$ (Table III). This same dose of the inhibitor blocked by $>95 \%$ the incorporation of labeled leucine into cell proteins and also prevented diC8-dependent cell adhesion. To determine whether TPA or diC8 could have specifically induced the formation of PGH synthase, we first determined whether the rate of enzyme formation in TPA-treated cells was sufficient to account for the rapid increase in $\mathrm{TXB}_{2}$ synthesis observed in the time course experiment shown in Fig. 3. Evidence for this was provided by experiments with HL-60 cells that had been pretreated with aspirin to block irreversibly the activity of the PGH synthase (37). When we subsequently removed the aspirin, then treated the cells with TPA, we found that a significant stimulation of $\mathrm{TXB}_{2}$ synthesis occurred within $1 \mathrm{~h}$ and that a stimulation equivalent to that observed in TPA-treated control cells occurred within 4-6 h (Fig. 7).

To obtain more direct evidence for a stimulatory effect of TPA and diC8 on the PGH synthase, we both measured the activity of the enzyme and estimated the mass of the enzyme in cell-free preparations. When we measured the kinetics of synthesis of $\mathrm{TXB}_{2}, \mathrm{PGE}_{2}$, and 6-keto-PGF ${ }_{1 \alpha}$ from exogenous $\mathrm{AA}$ in microsomes prepared from undifferentiated and cells that had been induced to differentiate into macrophages either by TPA or diC8, we observed large increases in the $V_{\max }$ values in differentiating cells as compared with control cells, but no changes in $K_{\mathrm{m}}$ values (Fig. 8, Table IV, results not shown).

When we estimated the mass of the enzyme by using two

Table III. TPA- and diC8-dependent TXB Synthesis from Exogenous AA Requires Translational Activity

\begin{tabular}{lc}
\hline Additions & $\mathrm{TXB}_{2}$ \\
\hline & $p g / 10^{6}$ cells \\
Control & $105 \pm 25$ \\
$10 \mathrm{nM}$ TPA & $1,990 \pm 160$ \\
$10 \mathrm{nM}$ TPA $+10 \mu \mathrm{g} / \mathrm{ml} \mathrm{cyclo}$ & $188 \pm 95$ \\
$0.1 \mathrm{nM}$ TPA & $195 \pm 72$ \\
$30 \mu \mathrm{M}$ diC8 & $390 \pm 60$ \\
$30 \mu \mathrm{M} \mathrm{diC} 8+0.1 \mathrm{nM}$ TPA & $2,480 \pm 190$ \\
$30 \mu \mathrm{M}$ diC8 $+0.1 \mathrm{nM}$ TPA $+10 \mu \mathrm{g} / \mathrm{ml}$ cyclo & $240 \pm 125$
\end{tabular}

Cells were cultured as described in Fig. $1.10 \mu \mathrm{g} / \mathrm{ml}$ cycloheximide was added in $50 \mu$ lof Dulbecco's PBS 30 min before addition of DIC8 and TPA. At $5 \mathrm{~h}$ parallel cultures were incubated with $10 \mu \mathrm{M}$ AA for 60 min and the concentration of $\mathrm{TXB}_{2}$ was determined as described in Methods. Inclusion of cycloheximide (cyclo) in the culture medium did not compromise viability of the cells as judged by exclusion of trypan blue or release of LDH. Numbers represent means of duplicate dishes \pm standard deviation. 


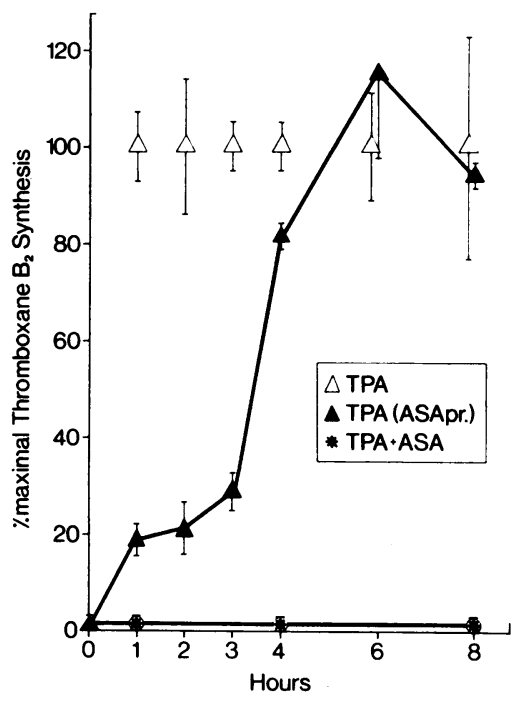
$\mathrm{TXB}_{2}$ was determined as described in Methods. The data points represent means of triplicate determinations \pm standard deviation.

monoclonal antibodies directed against different antigenic sites on sheep seminal vesicle PGH synthase, we were unable to detect measurable amounts in undifferentiated cells. In contrast, the monoclonal antibodies detected significant amounts of PGH synthase in HL-60 cells that had been induced to differentiate by TPA (Table V).

\section{Discussion}

Many studies have shown that both adherent, blood-derived monocytes and tissue macrophages can respond to immune complexes and other stimuli by releasing unesterified AA from endogenous phospholipids and then converting the $\mathrm{AA}$ into icosanoids (38-42). Such cells seem to form preferentially $\mathrm{TXB}_{2}$, $\mathrm{PGE}_{2}$, and leukotriene $\mathrm{B}_{4}$. There is evidence also that the release of AA from monocytes/macrophages may be rate limiting for icosanoid biosynthesis. For example, in response to opsonized

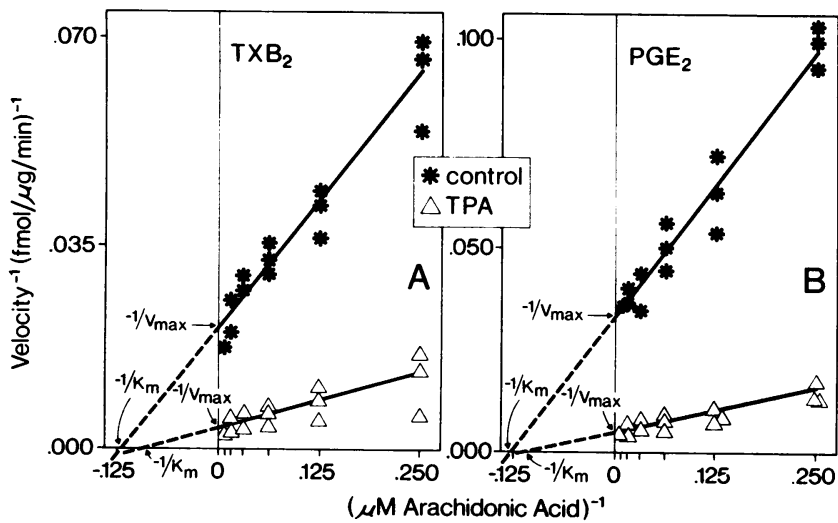

Figure 8. Kinetic parameters of microsomal $\mathrm{TXB}_{2}$ and $\mathrm{PGE}_{2}$ synthesis in control and TPA-treated HL-60 cells. Cells were cultured and TPA added as described in Fig. 1. After $12 \mathrm{~h}$ microsomes from control and TPA-treated cells were prepared and microsomal $(A) \mathrm{TXB}_{2}$ synthesis and $(B) \mathrm{PGE}_{2}$ synthesis were determined as described in Methods. The results were subjected to linear regression analyses. The data points indicated in the figure represent means of duplicate determinations in each of three independent experiments.
Table IV. Comparison between the Kinetic Parameters of $\mathrm{TXB}_{2}$ Synthesis in Microsomes Prepared from Control HL-60 Cells and Cells Treated with diC8 and/or TPA

\begin{tabular}{|c|c|c|}
\hline \multirow[b]{2}{*}{ Additions } & \multicolumn{2}{|l|}{$\mathrm{TXB}_{2}$} \\
\hline & $V_{\max }$ & $K_{\mathbf{m}}$ \\
\hline & 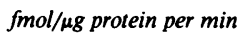 & $\mu M A A$ \\
\hline Control & $47.5 \pm 5.9$ & $8.0 \pm 2.6$ \\
\hline 10 nM TPA & $253.3 \pm 57.4$ & $7.4 \pm 3.3$ \\
\hline $0.1 \mathrm{nM}$ TPA & $57.9 \pm 10.6$ & $10.8 \pm 1.7$ \\
\hline \multicolumn{3}{|l|}{$0.1 \mathrm{nM}$ TPA $+30 \mu \mathrm{M}$ diC 8} \\
\hline single dose & $295.4 \pm 33.3$ & $8.4 \pm 1.5$ \\
\hline $70 \mu \mathrm{M}$ diC8 single dose & $90.0 \pm 15.0$ & $8.6 \pm 3.2$ \\
\hline \multicolumn{3}{|l|}{$30 \mu \mathrm{M}$ diC8 loading dose } \\
\hline$+4 \times 10 \mu \mathrm{M}$ diC 8 & & \\
\hline maintenance doses hourly & $376.0 \pm 22.1$ & $9.2 \pm 2.7$ \\
\hline
\end{tabular}

Cells were cultured and TPA was added as described in Fig. 1. diC8 was added as a single dose or repeatedly (four times at hourly intervals) as described in Fig. $6.12 \mathrm{~h}$ after the first addition of diC8 or TPA, microsomes were prepared and assayed for PGH synthase activity as described in Methods and Fig. 8. The data represent means of three experiments \pm standard deviation.

zymosan, mouse peritoneal macrophages release unesterified AA and synthesize PGs after a lag time of $\sim 15 \mathrm{~min}(40)$. In contrast, similar cells, incubated in the absence of a particulate stimulus, but in the presence of added unesterified AA or $\mathrm{Ca}^{2+}$ ionophore, apparently produce icosanoids without delay (43). These and other results have led to the concept that the induction of icosanoid synthesis in macrophages requires the activation of phospholipases, but may not require the activation or induced synthesis of enzymes that convert unesterified AA into oxidized products (44).

The important possibility remains, however, that the activity of enzymes, such as PGH synthase, that directly catalyze the formation of icosanoids, may be tightly regulated during one or

Table V. Estimation of HL-60 PGH Synthase Mass by Use of Cross-reacting Monoclonal Antibodies Directed against Sheep Seminal Vesicle PGH Synthase

\begin{tabular}{ll}
\hline Additions & Synthase mass \\
\hline & $p g / \mu g$ HL-60 microsomal protein \\
Control & Not detectable \\
$10 \mathrm{nM}$ TPA & $1,190 \pm 350$
\end{tabular}

Cells were cultured and TPA added as described in Fig. $1.12 \mathrm{~h}$ after addition of TPA, microsomes of control and TPA-stimulated cells were prepared as described in Methods and assayed for the presence of PGH synthase using two monoclonal antibodies (cyo-1, cyo-5) directed against two antigenic sites on sheep seminal vesicle PGH synthase that cross-react with the human enzyme $(22,23)$ as described in Methods. To generate the standard curve, partially purified sheep seminal vesicle PGH synthase was used. The results are reported as picograms of standard PGH synthase per microgram of HL-60 microsomal protein. The data represent means of two assay samples \pm standard deviation. Similar results were obtained in a second experiment. 
more stages of macrophage "activation" or development. Regulation of these enzymes might explain the observation (45) that immunological "activation" of macrophages is associated with preferential synthesis of $\mathrm{TXB}_{2}$ at the expense of $\mathrm{PGE}_{2}$. In addition, regulation of enzymes of icosanoid biosynthesis might be presumed to occur at some stage during macrophage development because the icosanoid patterns of monocytes/macrophages differ considerably from those of other terminally differentiated white blood cells that are derived from the same pluripotent stem cells in the bone marrow $(5,39,41,42,44$, 46, 47).

The present study was performed to explore the possibility that enzymes that directly catalyze the synthesis of icosanoids may be upregulated during the differentiation of promyelocytic cells into macrophages. In initial experiments we treated the HL-60 cells with TPA or diC8 to initiate their differentiation into macrophages, then measured the synthesis of $\mathrm{TXB}_{2}$ in the presence of added unesterified AA. The rationale for adding exogenous unesterified AA to the cells was to allow icosanoid synthesis to proceed independently of the release of endogenous AA from cellular phospholipid stores. The results of these experiments support several main conclusions. First, unlike macrophages, undifferentiated HL-60 cells form very little $\mathrm{TXB}_{2}$ in response to either added unesterified $\mathrm{AA}$ or added $\mathrm{Ca}^{2+}$ ionophore (Figs. 1 and 2, Table I). These results are consistent with previous data obtained in HL-60 cells induced to differentiate into macrophages by $(\mathrm{OH})_{2}$ vitamin $\mathrm{D}_{3}(48)$. Secondly, TPAstimulated cells show an increased capacity to form $\mathrm{TXB}_{2}$ and two other products of the PGH synthase pathway, $\mathrm{PGE}_{2}$ and 6keto-PGF $F_{1 \alpha}$, early during the course of their differentiation into macrophages (Table I). Thirdly, this response probably depends on the activation of PKC because the only phorbol diesters that are effective are those that stimulate this enzyme (not shown), because diC 8 is effective (Figs. 4-6), and because several different inhibitors of PKC prevent both the differentiation of HL-60 cells into macrophages and the increased ability of the cells to synthesize $\mathrm{TXB}_{2}$ (Table II). These results are consistent with the recent report of Merrill et al. (57) indicating that phorbol diesterand diC8-dependent HL-60 macrophage differentiation is inhibited by the novel PKC inhibitor sphinganine, which may function physiologically as a negative effector of this enzyme. In subsequent experiments, we provided strong evidence that the increased ability of the HL-60 cells to synthesize $\mathrm{TXB}_{2}$, $\mathrm{PGE}_{2}$, and 6-keto-PGF $\mathrm{F}_{1 \alpha}$ depends on an induced biosynthesis of PGH synthase. This evidence was based on the following observations: (a) both added unesterified $\mathrm{AA}$ and added $\mathrm{Ca}^{2+}$ ionophore greatly promoted the synthesis of $\mathrm{TXB}_{2}$ in differentiating cells but not in undifferentiated cells (Figs. 1-3); (b) the effects of TPA or diC8 on $\mathrm{TXB}_{2}$ synthesis became evident after a lag period that was comparable with that shown by cells that were recovering from the effects of pretreatment with aspirin (Figs. 3 and 7); (c) the effects of TPA or diC8 on TXB $_{2}$ synthesis were prevented by cycloheximide (Table III); $(d)$ microsomes from TPA- or diC8-treated cells showed increased activity of PGH synthase (Fig. 8, Table IV); and, most importantly, (e) immunoassays of PGH synthase in TPA-treated cells demonstrated a marked increase in enzyme protein (Table V). We conclude, therefore, that PGH synthase is upregulated during the differentiation of HL-60 cells into macrophages.

Four questions remain, however: (a) What is the mechanism of the effect of PKC on the induction of PGH synthase? (b) Is the PGH synthase response part of a coordinated response in- volving several enzymes of icosanoid biosynthesis? (c) How does the enzyme response in differentiating macrophages differ from responses that may occur in other differentiating white blood cells? $(d)$ What is the functional significance of the response? Only partial answers to these questions can be given at present.

It is unclear whether PKC directly affects a specific step in the biosynthesis of PGH synthase or whether its effects on PGH synthase are only indirect. What does seem clear is that the effects of PKC on HL-60 cell differentiation and icosanoid synthesis are closely linked. Moreover, it appears that prolonged activation of the kinase may be required for both types of effect. This is suggested by the fact that a single dose of diC8, even at a high concentration, failed to induce maximal production of $\mathrm{TXB}_{2}$ or maximal adherence of the cells to the culture dish. In contrast, both effects occurred when a loading dose of diC8 was followed at hourly intervals by four successive maintenance doses of diC8 (Fig. 6). This is consistent with the work of Ebeling et al. (13) who showed that repeated addition of diC8 to HL-60 cells is required to maintain occupancy of the phorbol diester binding sites and induce macrophage differentiation. Interestingly, we found that a single dose of diC8 was nevertheless effective when added in conjunction with a subthreshold dose of TPA (Figs. 4 and 5). The basis for this synergism remains to be clarified. It is probable that a single dose of diC8 acts only transiently because it is rapidly metabolized. It is known, for example, that HL-60 cells can rapidly convert diC8 into phosphatidic acid (18), and that TPA competitively inhibits diacylglycerol lipase activity (49). One possibility, therefore, is that these reactions or others that metabolize diC8 might be affected by TPA. Alternatively, TPA might promote the accumulation of endogenous diacylglycerol or potentiate the effects of diC 8 by binding to cellular sites other than PKC.

As for the possibility that macrophage differentiation might be accompanied by the coordinately controlled upregulation of several enzymes in the icosanoid biosynthesis pathway, and the possibility that different patterns of coordinate control might operate during the differentiation of different types of white blood cells, little can be said at present except for the following: First, our observation that the synthesis of three different icosanoids increased during the differentiation of $\mathrm{HL}-60$ cells clearly raises the possibility that several different enzymes were upregulated in concert. Indeed, we observed greatly increased synthesis of $\mathrm{TXB}_{2}$ from $\mathrm{PGH}_{2}$ in differentiating, but not in undifferentiated cells (manuscript in preparation). Secondly, preliminary experiments with HL-60 cells that were induced to differentiate into granulocytes have provided evidence that the granulocyte- and macrophage-differentiation pathways are associated with different $\mathrm{TXB}_{2}$ responses. When we induced differentiation of $\mathrm{HL}$ 60 cells into granulocytes by treating the cells with dimethyl sulfoxide (DMSO) (50) for $5 \mathrm{~d}$, we found by morphologic examination that $>95 \%$ of the cell population had differentiated along the myeloid pathway: promyelocytes, 3\% (control 95\%); myelocytes, $36.5 \%$; metamyelocytes, $36.5 \%$; stab cells, $13.5 \%$; polymorphonuclear leukocytes, $10.5 \%$. Furthermore, the cells showed an increased synthesis of $\mathrm{TXB}_{2}$ in the presence of added unesterified AA, as has been reported by others (51). However the effect of DMSO on $\mathrm{TXB}_{2}$ synthesis was relatively small, reaching only $25 \%$ of that of TPA. In addition, the kinetics of $\mathrm{TXB}_{2}$ synthesis were different: whereas treatment with TPA resulted in maximal synthesis of $\mathrm{TXB}_{2}$ within 3-6 h, treatment with DMSO induced maximal synthesis rates within $24 \mathrm{~h}$. Retinoic acid, another inducer of granulocyte differentiation (52), 
was even less active than DMSO in stimulating $\mathrm{TXB}_{2}$ synthesis within the same period of time. Bonser et al. (53) and Anthes et al. (54) have previously shown that myeloid differentiation of HL-60 cells is associated with induction of the 5-lipoxygenase pathway and Lundberg et al. (55) demonstrated the appearance of the 15-lipoxygenase pathway in the same system. Experiments performed in our laboratory (unpublished observations) confirmed these previous results and extended them by demonstrating the appearance of the 5-lipoxygenase pathway in both the myeloid and the macrophage differentiation pathways. Further work will clearly be required to characterize the precise patterns of icosanoid biosynthesis in the granulocyte- and macrophagedifferentiation pathways and to show whether additional differences between the two types of responses exist.

Further work will also be required to establish the functional significance of icosanoid formation during macrophage differentiation. HL-60 cells are transformed cells and thus only models of normal promyelocytes. Furthermore, we used two unphysiological substances, TPA and diC8 to induce their differentiation. It will be important, therefore, to determine whether normal bone marrow promyelocytes respond to physiological differentiation factors by upregulating enzymes of icosanoid biosynthesis. A physiologic response system of this type might be particularly useful in the investigation of potential autocrine and paracrine effects of icosanoids. Indeed, Kurland and his colleagues (56) have already provided evidence that PGs formed by adherent monocytes can inhibit colony formation by granulocyte/macrophage stem cells derived from normal human bone marrow.

In summary, our results demonstrate that the differentiation of HL-60 cells into macrophages is associated with an early upregulation of PGH synthase. They show that this upregulation depends on induction of enzyme synthesis, and support the conclusion that formation of PGH synthase contributes critically to the regulation of the synthesis of $\mathrm{TXB}_{2}, \mathrm{PGE}_{2}$, and 6-keto$\mathrm{PGF}_{1 \alpha}$. They suggest that activation of $\mathrm{PKC}$ for $\sim 5 \mathrm{~h}$ is required for both the maximal induction of macrophage differentiation and the maximal induction of icosanoid biosynthesis. More work is needed now to elucidate the mechanism and functional significance of these effects.

\section{Acknowledgments}

We are indebted to Dr. W. Nastainzcyk, University of Saarland, for the generous gift of $\mathrm{PGH}_{2}$ and advice in this study, Dr. B. Sorg, German Cancer Research Center in Heidelberg for the generous gift of diC8, Dr. G. Fuerstenberger, German Cancer Research Center in Heidelberg for the generous gift of 4- $\alpha$-phorbol 12,13-didecanoate, Dr. W. Bundschuh, the Rechenzentrum of the University of Heidelberg for performing the statistical analyses, and Dr. W. E. Berdel, Technical University of Munich for the generous gift of alkyl-lysophospholipid and CP-46-6651. TFP $\mathrm{HCl}$ was a gift of Roehm Pharma $\mathrm{GmbH}$, Darmstadt.

This work was supported by the Deutsche Forschungsgemeinschaft

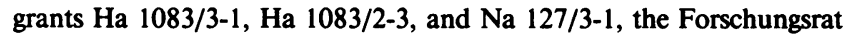
Rauchen und Gesundheit Hamburg, and the Howard Hughes Medical Institute Laboratory.

\section{References}

1. Dayer, J.-M., D. R. Robinson, and S. M. Krane. 1977. Prostaglandin production by rheumatic synovial cells: stimulation of a factor from human mononuclear cells. J. Exp. Med. 145:1399-2091.

2. Tanner, A. R., M. J. Arthur, and R. Wright. 1984. Macrophage activation, chronic inflammation, and gastrointestinal disease. Gut. 25: 760-783.

3. Ogekawa, T., P. E. Jonas, K. DeSchryver, A. Kawasaki, and P. Needleman. 1983. Metabolic and cellular alterations underlying the exxaggerated renal prostaglandin and thromboxane synthesis in ureter obstruction in rabbits: inflammatory response involving fibroblasts and mononuclear cells. J. Clin. Invest. 71:81-90.

4. Sheng, W. Y., T. A. Lysz, A. Wyche, and P. Needleman. 1983. Kinetic comparison and regulation of the cascade of microsomal enzymes involved in renal arachidonate and endoperoxide metabolism. J. Biol. Chem. 258:2188-2192.

5. Lefkowith, J. B., and P. Needleman. 1985. Arachidonate metabolism in renal injury. Adv. Prostaglandin Thromboxane Leukotriene Res. 13:121-131.

6. Ross, R. 1986. The pathogenesis of atherosclerosis: an update. $N$. Engl. J. Med. 314:488-500.

7. Rovera, G., D. Santoli, and C. Dansky. 1979. Human promyelocytic leukemia cells in culture differentiate into macrophage-like cells when treated with a phorbol ester. Proc. Natl. Acad. Sci. USA. 76:27792783.

8. Harris, P., and P. Ralph. 1985. Human leukemic models of myelomonocytic development: a review of the HL-60 and U-937 cell lines. J. Leukocyte Biol. 37:407-422.

9. Adams, D. O., and T. A. Hamilton. 1984. The cell biology of macrophage activation. Annu. Rev. Immunol. 2:283-318.

10. Korn, J. H., P. V. Halushka, and E. C. LeRoy. 1980. Mononuclear cell modulation of connective tissue function: suppression of fibroblast growth by stimulation of endogenous prostaglandin production. J. Clin. Invest. 65:543-554.

11. Evers, A. S., S. Murphree, J. E. Saffitz, B. A. Jakschik, and P. Needleman. 1985. Effects of endogenously produced leukotrienes, thromboxane, and prostaglandins on coronary vascular resistance in rabbit myocardial infarction. J. Clin. Invest. 75:992-999.

12. Fitzgerald, D. J., J. Doran, E. Jackson, and G. A. Fitzgerald. 1986. Coronary vascular occlusion mediated via thromboxane $A_{2}$-prostaglandin endoperoxide receptor activation in vivo. J. Clin. Invest. 77: 496-502.

13. Ebeling, J. G., G. R. Vandenbark, L. J. Kuhn, B. R. Ganong, R. M. Bell, and J. E. Niedel. 1985. Diacylglycerols mimic phorbol diester induction of leukemic cell differentiation. Proc. Natl. Acad. Sci. USA. 82:815-819.

14. Vandenbark, G. R., L. J. Kuhn, and J. E. Niedel. 1984. Possible mechanism of phorbol diester-induced maturation of human promyelocytic leukemia cells: activation of protein kinase C. J. Clin. Invest. 73: 448-457.

15. May, W. S., E. G. Lapetina, and P. Cuatrecasas. 1986. Intracellular activation of protein kinase $C$ and regulation of the transferrin receptor by diacylglycerol is a spontaneously reversible process that is associated with rapid formation of phosphatidic acid. Proc. Natl. Acad. Sci. USA. 83:1281-1284.

16. Niedel, J. E., L. J. Kuhn, and G. R. Vandenbark. 1983. Phorbol diester receptor copurifies with protein kinase C. Proc. Natl. Acad. Sci. USA. 80:36-39.

17. Kikkawa, U., Y. Takai, Y. Tanaka, R. Migake, and Y. Nishizuka. 1983. Protein kinase $C$ as a possible receptor protein of tumor-promoting phorbol esters. J. Biol. Chem. 258:11441-11445.

18. Nishizuka, Y. 1984. The role of protein kinase $C$ in cell surface signal transduction and tumor promotion. Nature (Lond.). 308:693-698.

19. Habenicht, A. J. R., M. Goerig, D. Rothe, R. Gronwald, U. Loth, G. Schettler, B. Kommerell, and R. Ross. 1985. Human platelet-derived growth factor stimulates prostaglandin synthesis by activation and rapid de novo synthesis of cyclooxygenase. J. Clin. Invest. 75:1381-1387.

20. Habenicht, A. J. R., A. Dresel, M. Goerig, J. Weber, J. Glomset, R. Ross, and G. Schettler. 1986. Low density lipoprotein receptor-dependent prostaglandin synthesis in Swiss 3T3 cells stimulated by plateletderived growth factor. Proc. Natl. Acad. Sci. USA. 83:1344-1348.

21. Granstroem, E., and H. Kindahl. 1978. Radioimmunoassay of 
prostaglandins and thromboxanes. Adv. Prostaglandin Thromboxane Res. 5:119-210.

22. Smith, W. L., and T. E. Rollins. 1982. Characteristics of rabbit anti PGH synthase antibodies and use in immunocytochemistry. Methods Enzymol. 86:213-222.

23. DeWitt, D. L., J. S. Day, J. A. Gauger, and W. L. Smith. 1982. Monoclonal antibodies against PGH synthase: an immunoradiometric assay for quantitating the enzyme. Methods Enzymol. 86:229-252.

24. Greenwood, F. C., W. M. Hunter, and J. S. Glover. 1963. The preparation of ${ }^{131} \mathrm{I}$-labelled human growth hormone of high specific radioactivity. Biochem. J. 89:114-123.

25. Deleted in proof.

26. Whiteley, P. J., and P. Needleman. 1984. Mechanism of enhanced fibroblast arachidonic acid metabolism by mononuclear cell factor. $J$. Clin. Invest. 74:2249-2253.

27. Lowry, O. H., N. J. Rosebrough, A. L. Farr, and R. J. Randell. 1951. Protein measurement with the folin phenol reagent. J. Biol. Chem. 193:265-275.

28. Ohuchi, K., and L. Levine. 1978. Stimulation of prostaglandin synthesis by tumor-promoting phorbol-12,13-diesters in canine kidney (MDCK) cells. J. Biol. Chem. 253:4783-4790.

29. Borgeat, P., and B. Samuelsson. 1979. Arachidonic acid metabolism in polymorphonuclear leukocytes: effects of ionophore A 23187. Proc. Natl. Acad. Sci. USA. 76:2148-2152.

30. Castagna, M., Y. Takai, K. Kaibuchi, K. Sano, U. Kikkawa, and Y. Nishizuka. 1982. Direct activation of calcium-activated, phospholipiddependent protein kinase by tumor-promoting phorbol esters. J. Biol. Chem. 257:7847-7851.

31. Feuerstein, N., and H. L. Cooper. 1983. Rapid protein phosphorylation induced by phorbol ester in HL-60 cells. J. Biol. Chem. 258: 10786-10793.

32. Feuerstein, N., and H. L. Cooper. 1984. Rapid dephosphorylation of specific proteins induced by phorbol ester in HL-60 cells: further characterization of the phosphorylation of 17-kilodalton and 27-kilodalton proteins in myeloid leukemic cells and human monocytes. J. Biol. Chem. 259:2782-2788.

33. Wise, B. C., D. B. Glass, C.-H. Jen Chou, R. L. Raynor, N. Katch, R. C. Schatzman, R. S. Turner, R. F. Kibler, and J. F. Kuo. 1982. Phospholipid sensitive $\mathrm{Ca}^{++}$-dependent kinase from heart II. Substrate specifity and inhibition by various agents. J. Biol. Chem. 257: 8489-8495.

34. Helfman, D. M., K. C. Barnes, J. M. Kinkade, Jr., W. R. Vogler, M. Shoji, and J. F. Kuo. 1983. Phospholipid-sensitive $\mathrm{Ca}^{++}$-dependent protein phosphorylation system in various types of leukemic cells from human patients and in human leukemic cell lines HL-60 and K562, and its inhibition by alkyl-lysophospholipid. Cancer Res. 43:2955-2961.

35. Shoji, M., W. R. Vogler, and J. F. Kuo. 1985. Inhibition of phospholipid/ $\mathrm{Ca}^{++}$-dependent protein kinase and phosphorylation of leukemic cell proteins by CP-46,665-1, a novel antineoplastic lipoidal amine. Biochem. Biophys. Res. Commun. 127:590-595.

36. Hidaka, H., M. Inagaki, S. Kawamoto, and Y. Sasaki. 1984. Isoquinolinesulfonamides, novel and potent inhibitors of cyclic nucleotide dependent protein kinase and protein kinase C. Biochemistry. 23:50365041.

37. Roth, G. R., N. Stanford, and P. W. Majerus. 1975. Acetylation of prostaglandin synthetase by aspirin. Proc. Natl. Acad. Sci. USA. 72: 3073-3076.

38. Majerus, W. P. 1983. Arachidonate metabolism in vascular disorders. J. Clin. Invest. 72:1521-1525.

39. Hammarstroem, S. 1983. Leukotrienes. Annu. Rev. Biochem. 52: 355-377.

40. Scott, W. A., J. M. Zrike, A. L. Hamill, J. Kempe, and Z. A. Cohn. 1980. Regulation of arachidonic acid metabolism in macrophages. J. Exp. Med. 152:324-335.

41. Davidson, E. M., M. V. Doig, A. W. Ford-Hutchinson, and
M. J. H. Smith. 1980. Prostaglandin and thromboxane production by rabbit polymorphonuclear leukocytes and rat macrophages. Adv. Prostaglandin Thromboxane Res. 8:1661-1663.

42. Lewis, R. A., and K. F. Austen. 1984. The biologically active leukotrienes, biosynthesis, functions, and pharmacology. J. Clin. Invest. 73:889-897.

43. Scott, W. A., N. A. Pawlowski, M. Andreach, and Z. A. Cohn. 1982. Resting macrophages produce distinct metabolites from exogenous arachidonic acid. J. Exp. Med. 155:535-547.

44. Aderem, A. A., W. A. Scott, and Z. A. Cohn. 1985. Signalresponse coupling in the arachidonic acid cascade of macrophages. In Mononuclear Phagocytes, Characteristics, Physiology, and Function. R. Van Furth, editor. Martinus Nijhoff Publishers, Dordrecht, The Netherlands. 311-317.

45. Tripp, C. S., K. M. Leahy, and P. Needleman. 1985. Thromboxane synthase is preferentially conserved in activated mouse peritoneal macrophages. J. Clin. Invest. 76:898-901.

46. Burgess, A., and N. Nicola. 1983. Hemopoietic cells. In Growth Factors and Stem Cells. A. Burgess, and N. Nicola, editors. Academic Press, Inc., New York. 43-91.

47. Needleman, P., J. Turk, B. A. Jakschik, A. R. Morrison, and J. B. Lefkowith. 1986. Arachidonic acid metabolism. Annu. Rev. Biochem. 55:69-102.

48. Honda, A., I. Morita, S. Murota, and Y. Mori. 1986. Appearance of the arachidonic acid metabolic pathway in human promyelocytic leukemia (HL-60) cells during monocyte differentiation: enhancement of thromboxane synthesis by $1 \alpha, 25$-dihydroxyvitamin D-3. Biochim. Biophys. Acta. 877:423-432.

49. Chabbot, H., and M. C. Cabot. 1986. Phorbol diesters inhibit enzymatic hydrolysis of diacylglycerols in vitro. Proc. Natl. Acad. Sci. USA. 83:3126-3130.

50. Collins, S. J., F. W. Ruscetti, R. E. Gallagher, and R. C. Gallo. 1979. Normal functional characteristics of cultured human promyelocytic leukemia cells (HL-60) after induction of differentiation by DMSO. $J$. Exp. Med. 149:969-974.

51. Bonser, R. W., M. I. Siegel, R. T. McConnell, and P. Cuatrecasas. 1981. The appearance of phospholipase and cyclooxygenase activities in the human promyelocytic leukemia cell line HL-60 during dimethyl sulfoxide-induced differentiation. Biochem. Biophys. Res. Commun. 98: 614-620.

52. Honma, Y., K. Takenaga, K. Katsukabe, and M. Hozumi. 1980. Induction of differentiation of cultured human promyelocytic leukemia cells by retinoids. Biochem. Biophys. Res. Commun. 95:507-511.

53. Bonser, R. W., M. I. Siegel, R. T. McConnell, and P. Cuatrecasas. 1981. Chemotactic peptide stimulated endogenous arachidonic acid metabolism in HL-60 granulocytes. Biochem. Biophys. Res. Commun. 102: 1269-1275.

54. Anthes, J. C., R. W. Bryant, M. W. Musch, N. G. Kwokei, and M. J. Siegel. 1986. Calcium ionophore and chemotactic peptide stimulation of peptidoleukotriene synthesis in DMSO-differentiated HL-60 cells. Inflammation. 10:145-156.

55. Lundberg, U., C. N. Serhan, and B. Samuelsson. 1985. Appearance of an arachidonic acid 15-lipoxygenase pathway upon differentiation of the human promyelocytic cell-line HL-60. FEBS (Fed. Eur. Biochem. Soc.) Lett. 185:14-18.

56. Kurland, J. I., R. S. Bockman, H. E. Broxmeyer, and M. A. S. Moore. 1978. Limitation of excessive myelopoiesis by the intrinsic modulation of macrophage-derived prostaglandin E. Science (Wash. DC). 199:552-555.

57. Merrill, A. H., A. M. Sereni, V. L. Stevens, Y. A. Hannun, R. M. Bell, and J. M. Kinkade, Jr. 1986. Inhibition of phorbol esterdependent differentiation of human promyelocytic leukemic (HL-60) cells by sphinganine and other long-chain bases. J. Biol. Chem. 261: 12610-12615. 